\title{
Characterization of Aerobic Spore-Forming Bacteria Isolated From Raw Milk, Skim Milk Powder and UHT Milk
}

\author{
Sameh S. Yacoub ${ }^{1}$, Sherif M. Shamsia ${ }^{1}$, Sameh A. Awad ${ }^{2}$, Hamid M. Ziena ${ }^{1}$ and Nabil M. Safwat ${ }^{2}$
}

\begin{abstract}
Thermoduric and thermophilic aerobic spore-forming bacteria are the common causes of spoilage of pasteurized and Ultra-high-temperature (UHT) milk. The presence of high level of aerobic spore-forming bacteria in raw and recombined milk used in making UHT milk increased the spoilage and/or the reduced shelf life in the final product. In this study, 140 samples of (32) raw milk (RM), (8) skim milk powder (SMP) and (100) UHT milk were collected to isolate aerobic spore-forming bacteria. A total of 210 isolates of heat resistant bacteria were classified according to morphological, physiological and biochemical tests. Out of theses isolates, 144 strains from RM (102), SMP (25) and UHT milk (17) were expected to be Bacillus spp. The isolates were evaluated for proteolytic activity and lactose fermentation, $96.55 \%$ of the isolates were able to hydrolyze casein, while $42.76 \%$ of the isolates were able to ferment lactose. Thermophilic Bacillus species were the predominant isolates from raw milk and skimmed milk powder. While, mesophilic Bacillus species were the predominant in UHT milk.
\end{abstract}

Key Words: Raw milk, Skimmed milk, UHT milk, spore-forming bacteria, Bacillus spp.

\section{INTRODUCTION}

Milk is one of the widely consumed products in the world, highly susceptible to contamination by microorganisms and it is also a suitable medium for the rapid growth and multiplication of bacteria at favorable temperatures. It is necessary to use great care in the collection and handling of milk samples to prevent any extraneous contamination and to control the growth of organisms during transportation and storage of the milk (Srilakshmi, 1999).There are several types of bacteria which changes the properties of milk. Psychrotrophic microorganisms are able to grow at temperature below $7^{\circ} \mathrm{C}$. There are seven types of bacteria which change the properties of milk. They are often produce proteolytic and lipolytic enzymes. They include bacteria such as Staphylococcus aureus, Bacillus cereus, Pseudomonas aeruginosa, Proteus mirabilis, Escherichia coli, Micrococcus luteus and Serratia marcescens. Spores forming bacteria can withstand greater extremes of acidity, temperature and desiccation. Bacterial enzymes are most significant to milk spoilage (Megha \& Annadurai, 2014; Zewail et al.,2015.).

\footnotetext{
${ }^{1}$ Food, Dairy Science \& Technology Dept., Faculty of Agric., Damanhour Univ., Egypt.

2-Dairy Science \& Technology Dept., Faculty of Agric. El-Shatby,

Alexandria Univ., Egypt.

Received March 6, 2017, Accepted March 30, 2017
}

The UHT treatment is usually carried out at temperatures between $135-150{ }^{\circ} \mathrm{C}$ for $1-10$ seconds to achieve commercial sterility. The UHT processing of milk destroys all microorganisms that can grow under normal storage conditions (Lewis \& Deeth, 2009 \& Deeth, 2010). Almost all enzymes are also inactivated by UHT processing because the most enzymes in milk are inactivated at temperatures below $100{ }^{\circ} \mathrm{C}$, but some bacterial proteinases and lipases needs temperatures above $150{ }^{\circ} \mathrm{C}$ for inactivation (Kessler, 2002).

Bacillus spp. are often present in raw milk and play an important role in the spoilage of UHT milk (Crielly et al., 1994).The use of Ultra-high-temperature (UHT) processing should inactivate the spores of Bacillus species and result in fluid milk products with a long shelf-life without refrigeration. However, defects in UHT milk product stability have been reported (Klijn et al., 1997). This nonstability appeared to be caused by the presence of highly heat-resistant bacterial endospores which were first detected in UHT milk from southern Europe in 1985 and were later identified in other countries both in and outside Europe (Hammer et al., 1995). It thus became necessary to develop more efficient processes to inactivate this micro-organism completely and ensure milk commercial sterility.

Aerobic spore-forming members are of importance to the dairy industry as spores of these microorganisms, present in raw milk can survive pasteurization and other processing events and ultimately become incorporated into final products (Cook \& Sandeman, 2000, Huck et al., 2007, Coorevits et al., 2008). Spores of Bacillus spp. appear regularly in stable environment and they usually represent a secondary contamination of milk during milking process. Besides predominant mesophilic species, e.g. B. licheniformis, B. subtilis and B. pumilus, dominant psychrotrophic isolates are represented by $B$. cereus strains. These aerobic spores are common in raw milk and linked to spoilage in pasteurized milk and UHT products (Stenfors \& Granum, 2001, McGuiggan et al., 2002). In liquid-based dairy products, bacterial spores are rarely a health issue but may cause product spoilage under inadequate pasteurization/storage conditions, leading to product downgrades and losses in 
revenue. For dairy powders, thermophilic spore-forming bacilli can survive in the final product (Burgess et al., 2010). The presence of mesophilic sporeforming microorganisms in high levels in UHT products will be able to cause the deterioration and/ or the reduction of shelf life (Fernanda et al., 2010). Also once present in a processing facility, spores from some thermophilic spore-former organisms can germinate and multiply in biofilms in dairy processing equipment (Burgess et al., 2009, 2010).

Genera Bacillus are formed by Gram-positive rods able to produce endo-spores resistant to unfavourable external conditions (Logan \& De Vos, 2009) that can be distinguished from other spore-formers (Sporolactobacillus, Clostridium, Desulfotomaculum, Sporosarcina or Thermoactinomycetes) due to their aerobic nature (strict or facultative), rod-shaped cells and catalase synthesis (Slepecky \& Hemphill, 2006).

Most often, Bacillus spp. is detected and isolated by methods based on the resistance of spores to heating or ethanol. However, direct isolation of particular species requires a selective medium or other selective conditions that are available only for a few species (Logan \& De Vos, 2009). Due to the large number of species and often incomplete descriptions of newly reported species, Bacillus species differentiation is difficult (Holt et al., 1994).Traditional identification has been based on Gram stain, colony morphology, motility and biochemical testing, which are time-consuming, somewhat subjective, and labor intensive procedures. Both traditional and automated identification systems have difficulty identifying some Bacillus species and do not differentiate between strains (Webb et al., 2003).

To prevent contamination of milk and dairy products with aerobic spore-forming bacteria, it is important to ensure that contamination of raw milk is minimised. To achieve this, the nature and origin of spores and in particular of spores in raw milk must be better understood. Although the incidence of Bacillus species in dairy products from different geographical areas has been widely investigated (Montanari et al., 2004, Scheldeman et al., 2005).

In Egypt, there is shortage in production of high quality raw milk. So, some dairy factories used low quality raw milk or milk powder (skimmed or full cream) or mix of raw milk with milk powder. Low quality of raw ingredients could increase the defects in UHT milk during production and/or during storage (shelf life). Therefore, the aims of study were to evaluate the microbiological quality of ingredients (raw milk and skimmed milk powder) that could be used in producing UHT milk and then isolate and characterize some of aerobic spore-forming bacteria (Bacillus species) from raw ingredients and ultra-high temperature treated milk (UHT Milk).

\section{MATERIALS AND METHODS}

\section{Samples collection:}

Thirty two raw cow's milk samples were collected during the period between May and September, 2015 from farms and milk collection centers in Alexandria and El-Beheira Governorates, Egypt. Samples were collected and were kept in ice box and transferred to lab for not more than $4 \mathrm{hrs}$.

Eight samples of skimmed milk powder from five different brands and countries. Each sample (100g) was obtained in clean, dry and sterile polyethylene bags along with sterile spatula.

According to codex and Egyptian standards specifications (ESS), UHT milk product is not allowed to be released to marketing before incubation at $30^{\circ} \mathrm{C}$ for 7 days. In a factory of dairying, UHT milk batch showed un-sterility defects after incubation period and before releasing, so one hundred samples of defected UHT milk were obtained from this batch. All samples were transferred to lab under sterile conditions.

\section{Sample preparation:}

Using aseptic technique, aliquots of $1 \mathrm{ml}$ of the raw milk (RM) and UHT milk samples were transferred into test tube containing $9 \mathrm{ml}$ sterile saline and mixed for 2 min using a vortex. On the other hand, skimmed milk powder (SMP) samples were rehydrated by dissolving $10 \mathrm{~g}$ samples with $90 \mathrm{ml}$ of sterile saline in a sterile polyethylene bags and shaking them at $160 \mathrm{rpm}$ for 5 min at room temperature using stomacher according to Standard Methods for the Examination of Dairy Products (1978).

\section{Enumeration of total viable:}

Total viable counts of all samples were enumerated using nutrient agar medium. The plates were incubated at $32^{\circ} \mathrm{C}$ for $48 \mathrm{~h}$ (Difco, 1984). The bacterial count was expressed as $\mathrm{cfu} / \mathrm{ml}$ or $\mathrm{g}$ milk.

\section{Enumeration of aerobic spore-forming bacteria:}

Aerobic spore-forming bacteria was enumerated on the same media used in total viable count but the samples of RM and SMP after preparation were heated in water bath at $80^{\circ} \mathrm{C}$ for 10 min then they cooled suddenly to the room temperature before transferring one $\mathrm{ml}$ aliquots in petri dishes. The plates were incubated at $32^{\circ} \mathrm{C}$ for $48 \mathrm{~h}$ (Standard Methods for the Examination of Dairy Products, 1978). The bacterial count was expressed as cfu/ $\mathrm{ml}$ or $\mathrm{g}$ milk. 


\section{Isolation of aerobic spore-forming bacteria:}

Some of colonies, which suspected to be Bacillus spp. according to the colony morphology, spread with unusual characteristics (e.g., slimy, crusty, dry, embedded or forming skin-like pellicles), were sub cultured to purity on a non-selective medium Nutrient Agar (NA) plates. A total of 210 isolates "153, 33 and 24 " from "RM, SMP and UHT milk respectively", were purified and characterized. The pure isolates were inoculated into nutrient broth (Merck, Germany) and stored in $15-20 \%$ glycerol at $-20{ }^{\circ} \mathrm{C}$ for further analysis.

\section{Classification of aerobic spore-forming isolates:}

Pre-identification tests were carried out Gram type, cell morphology, catalase production, ability to growth at $7{ }^{\circ} \mathrm{C}$ and $50^{\circ} \mathrm{C}$, ability to hydrolyze casein and lactose fermentation.

\section{Gram staining:}

The biochemical structure of bacterial cell wall is considered to be the main responsible to constituent introduced in the Gram staining method according to (Difco, 1984).

\section{Catalase test:}

The presence or absence of catalase activity is an important taxonomical characteristic of bacteria. Aerobic and facultative anaerobic growing microorganisms exhibit catalase activity, while in obligate anaerobic bacteria this enzyme is absent, resulting in sensitivity to oxygen. For catalase test, 3\% $(\mathrm{v} / \mathrm{v})$ of hydrogen peroxide solution was dropped on the colony under examination and observed for the production of effervescence. Yeast was used as a positive control for the catalase test (Wong et al., 1988).

\section{Growth at $7{ }^{\circ} \mathrm{C}$ (Psychrotrophic aerobic spore-} forming bacteria):

The ability of isolates to grow at $7^{\circ} \mathrm{C}$ was carried out as follow; each tested isolate was inoculated in nutrient agar medium at $7^{\circ} \mathrm{C}$ for $7-10$ days. The growth was observed in the medium and an un-inoculated plate was incubated under the same condition as a control (Standard Methods for the Examination of Dairy Products, 1978).

\section{Growth at $50{ }^{\circ} \mathrm{C}$ (Thermophilic aerobic spore-} forming bacteria):

The ability of isolates to grow at $50^{\circ} \mathrm{C}$ was carried out as following; each tested isolate was inoculated in nutrient agar medium at $50^{\circ} \mathrm{C}$ for 3 days. The growth was observed in the medium and an un-inoculated plate was incubated under the same condition as a control (Standard Methods for the Examination of Dairy Products, 1978).

\section{Casein hydrolysis test:}

The casein hydrolysis test is used to identify bacteria capable of hydrolyzing casein with the enzyme casease. The test was carried out as following inoculum from each tested isolate was streaked on petri dish of skim milk agar medium, Difco (1984). The inoculated petri dishes were incubated at $32{ }^{\circ} \mathrm{C}$ for $48 \mathrm{hrs}$. The growth was observed in the medium and an un-inoculated petri dish was incubated under the same condition as a control. The results are determined as clearing of the agar around the bacterial growth indicates casein hydrolysis.

\section{Lactose fermentation test:}

The purpose is to see if the isolates can ferment the lactose as a carbon source. The test was carried out as following; an inoculums from each tested pure isolate transferred aseptically to a sterile tube of phenol red lactose broth medium, Difco (1984). The inoculated tube was incubated at $35-37^{\circ} \mathrm{C}$ for $24 \mathrm{hrs}$. The growth was observed in the medium and an un-inoculated tube was incubated under the same condition as a control. The results are determined. A positive test consists of a color change from red to yellow.

\section{RESULTS AND DISCUSSION}

Enumeration of total viable and aerobic sporeforming bacteria for raw milk, skim milk powder and UHT-milk:

The results in Table (1) show that the mean counts of total viable count ranged between logs 5.06 and 8.03 $\mathrm{cfu} / \mathrm{ml}$ in raw milk samples. Results show that all RM samples were contain highly bacterial levels or counts according to the ESS (No, 0154-01/2005) the average of total number of micro-organisms should not exceed 100.000 per $\mathrm{ml}(\log 5 \mathrm{cfu} / \mathrm{ml})$ of raw cow's milk from primary production. Hence, $75 \%$ of raw milk samples may be considered of bad quality. As shown in Table (1) aerobic spore-forming bacteria count ranged between $<10$ and $\log 3.53 \mathrm{cfu} / \mathrm{ml}$ in raw milk samples. This finding differs from those reported by (Mikolajcik \& Simon, 1978), who found that raw milk is the usual source of spore-forming bacteria in finished dairy products. Their numbers before pasteurization seldom exceed 5,000 cfu/ ml.

Total viable bacteria of SMP ranged between $\log 2.4$ and $3.2 \mathrm{cfu} / \mathrm{g}$ in samples of skim milk powder. Also, aerobic spore-forming bacteria count ranged between $<10$ and $\log 2.85 \mathrm{cfu} / \mathrm{g}$ in samples of skim milk powder.

Results in Table (1) show that the defected in unsterility UHT milk batch was at level of $17 \%$. The count of TVB was lower than 10 colonies per $0.1 \mathrm{ml}$. EGregulation 1623/2005 for long life sterilized milk requires that the number of colony counted from 
incubated (30 $-35^{\circ} \mathrm{C}$ for 7 days) unopened UHT-cartons, does not exceed 10 colony forming unit (cfu) per $1 \mathrm{ml}$ (Scheldeman et al., 2006). Bacillus spp. spores may occur also in UHT milk, as reported by Bahout (2000) who found the spores in $18.3 \%$ samples investigated at a count of $2.6 \times 10^{2} \mathrm{cfu} / \mathrm{ml}$.

Classification of aerobic spore-forming bacteria isolated from raw milk, skimmed milk powder and UHT milk:

Pre-identification results of obtained isolates from RM (153), SMP (33) and UHT-milk (24) are illustrated in Tables (3, 4 and 5). Two hundred and ten heat resistant $\left(80^{\circ} \mathrm{C} / 10 \mathrm{~min}\right)$ isolates were phenotypically identified. Results show that $66.67,75.76$ and $70.83 \%$ of total isolates for RM, SMP and UHT-milk were aerobic spore-forming bacteria. Gram-positive, rodshaped bacteria that differentiate into heat-resistant endo-spores under aerobic conditions are placed in the genus Bacillus (Priest, 1993). After that the Bacillus spp. isolates were examined with pre-identification tests.

Bacillus spp. isolates were classified according to their growth ability at different temperatures into three divisions $\left(7,32\right.$ and $\left.50^{\circ} \mathrm{C}\right)$. Each division was classified to three sub-division according to their ability to hydrolyze casein and/or to ferment lactose. Depending on obtained data, the isolates classification is given at end in 9 groups as show in Table (2).

Table 1. Total viable and aerobic spore-forming bacteria counts for raw milk (RM), skim milk powder (SMP) and UHT milk

\begin{tabular}{|c|c|c|c|c|c|c|c|}
\hline \multicolumn{8}{|c|}{ Sample } \\
\hline \multirow{3}{*}{$\begin{array}{l}\text { No. } \\
\text { of sample }\end{array}$} & \multicolumn{2}{|c|}{$\mathbf{R M}$} & \multicolumn{2}{|c|}{ SMP } & \multicolumn{3}{|c|}{ Defected UHT-milk } \\
\hline & TVB & ASB & TVB & $\overline{\text { ASB }}$ & & TVB & ASB \\
\hline & $\log \mathbf{c f u} / \mathbf{m l}$ & $\log \mathrm{cfu} / \mathrm{ml}$ & $\log \mathrm{cfu} / \mathrm{g}$ & $\log \mathbf{c f u} / \mathrm{g}$ & $\log$ & cfu/0.1ml & $\log \mathrm{cfu} / 0.1 \mathrm{ml}$ \\
\hline 1 & 6.82 & 2.56 & 3.08 & 1.95 & & $<10$ & $<10$ \\
\hline 2 & 6.83 & 3.51 & 2.40 & $<10$ & & $<10$ & $<10$ \\
\hline 3 & 5.59 & 3.53 & 2.48 & 2.40 & & $<10$ & $<10$ \\
\hline 4 & 6.60 & 2.36 & 2.78 & 2.30 & & $<10$ & $<10$ \\
\hline 5 & 5.74 & 2.14 & 3.04 & 2.79 & & $<10$ & $<10$ \\
\hline 6 & 5.57 & 2.92 & 3.08 & 2.85 & & $<10$ & $<10$ \\
\hline 7 & 6.55 & 1.47 & 3.20 & 2.30 & & $<10$ & $<10$ \\
\hline 8 & 5.72 & $<10$ & 3 & 2.08 & & $<10$ & $<10$ \\
\hline 9 & 5.98 & $<10$ & - & - & & $<10$ & $<10$ \\
\hline 10 & 5.41 & 2.23 & - & - & & $<10$ & $<10$ \\
\hline 11 & 5.40 & 2.04 & - & - & & $<10$ & $<10$ \\
\hline 12 & 5.49 & 2.11 & - & - & & $<10$ & $<10$ \\
\hline 13 & 5.06 & 2.23 & - & - & & $<10$ & $<10$ \\
\hline 14 & 7.04 & 2.17 & - & - & & $<10$ & $<10$ \\
\hline 15 & 7.50 & 2.30 & - & - & & $<10$ & $<10$ \\
\hline 16 & 7.70 & 2.47 & - & - & & $<10$ & $<10$ \\
\hline 17 & 7.94 & 2.11 & - & - & & $<10$ & $<10$ \\
\hline 18 & 7.74 & 2.44 & - & - & & - & - \\
\hline 19 & 5.29 & 1.90 & - & - & & - & - \\
\hline 20 & 8.01 & 2.36 & - & - & & - & - \\
\hline 21 & 7.71 & 2.34 & - & - & & - & - \\
\hline 22 & 7.77 & 2.32 & - & - & & - & - \\
\hline 23 & 7.77 & 2.32 & - & - & & - & - \\
\hline 24 & 7.17 & 2.27 & - & - & & - & - \\
\hline 25 & 7.79 & 2.14 & - & - & & - & - \\
\hline 26 & 7.80 & 2.14 & - & - & & - & - \\
\hline 27 & 5.32 & 1.47 & - & - & & - & - \\
\hline 28 & 7.77 & 2.32 & - & - & & - & - \\
\hline 29 & 7.79 & 2.14 & - & - & & - & - \\
\hline 30 & 8.03 & 3.06 & - & - & & - & - \\
\hline 31 & 8.03 & 3.06 & - & - & & - & - \\
\hline 32 & 7.54 & 2.47 & - & - & & - & - \\
\hline
\end{tabular}


Table 2. Classification of Bacillus species isolates.

\begin{tabular}{lcccccccccc}
\hline Test & \multicolumn{1}{c}{ Group } & \multicolumn{1}{c}{} \\
\cline { 2 - 9 } & A & B & C & D & E & F & G & H & I \\
\hline Growth at $77^{\circ} \mathrm{C}$ & + & + & + & - & - & - & - & - & - \\
Growth at $32^{\circ} \mathrm{C}$ & + & + & + & + & + & + & + & + & + \\
Growth at $50^{\circ} \mathrm{C}$ & - & - & - & - & - & - & + & + & + \\
Casein hydrolysis (CH) & + & + & - & + & + & - & + & + & - \\
Lactose fermentation (LF) & + & - & + & + & - & + & + & - & + \\
\hline
\end{tabular}

(+) Bacillus isolates positive for test

(-) Bacillus isolates negative for test

\section{Pre-identification of Bacillus species isolated from raw milk:}

Data in Table(3) show the ability of 102 isolates from RM to grow at different temperatures. The results show that 18.62 and $55.88 \%$ of isolates were able to grow at 7 and $50{ }^{\circ} \mathrm{C}$, respectively.

All of Bacillus spp. isolates were able to hydrolyze casein. The most important spoilage organism in the dairy industry is undoubtedly $B$. cereus, causing 'bitty cream' (floating clumps of fat) due to lecithinase activity and 'sweet curdling' (curdling of milk without acidification) due to protease activity (Heyndrickx \& Scheldeman, 2002). While, $35.29 \%$ of isolates were able to hydrolyze casein and ferment lactose.

The results revealed to $47.37,30.77$ and $50 \%$ of psychrotrophic, mesophilic and thermophilic Bacillus spp. isolates, respectively were able to ferment lactose. As show in Fig. (1), Bacillus spp. isolates from RM samples were classified to 6 groups according to data given in Table (2). The group $\mathrm{H}(37.25 \%)$ was the predominant group, group G $(18.63 \%)$, group $\mathrm{E}$ (17.65\%), group B $(9.8 \%)$, group A $(8.83 \%)$ and group $\mathrm{D}(7.84 \%)$ were also present. While, noticed that the groups $\mathrm{C}, \mathrm{F}$ and I were not present in Bacillus spp. isolates from raw milk. According to bibliographic data, it was reported by Burton (1988) that Bacillus licheniformis is the most common spore isolated from raw milk.

\section{Pre-identification of Bacillus species isolated from skimmed milk powder:}

Pre-identification results of obtained 25Bacillus spp. isolates from 8 samples of SMP were showed in Table (4). The results show that $100 \%$ of isolates were able to grow at $32^{\circ} \mathrm{C}$, only $64 \%$ grow at $50^{\circ} \mathrm{C}$ and no grow at $7^{\circ} \mathrm{C}$. Thermophilic bacilli are the dominant contaminants of spray-dried milk powders. While, the isolates from SMP were not exhibited any growth at $7^{\circ} \mathrm{C}$. hydrolyze casein and lactose ferment

According to the results illustrated in Table (4), it was revealed that the proportion of $88 \%$ for total Bacillus spp. isolates was able to hydrolyze the casein. Also, $72.72 \%$ of hydrolyzed casein isolates were able to ferment lactose. On the other hand, $12 \%$ of isolates were able to ferment lactose.

The data in Table (4) show that $81.25 \%$ of thermophilic Bacillus spp. isolates were able to hydrolyze casein, the same ratio was able to ferment lactose. At same time, $62.5 \%$ of these isolates were able to hydrolyze casein and ferment lactose. On the other hand, 100\% mesophilic Bacillus spp. isolates were able to hydrolyze casein, while, $66.67 \%$ of these isolates were able to hydrolyze casein and ferment lactose.

The Bacillus spp. isolates form SMP samples were classified to 5 groups according to data given in Table (2) and Fig. (2). The group G (40\%) was the predominant group, followed by group D (24\%) then group E, group $\mathrm{H}$ and group I (12\%). While, noticed that the groups A, B, C and F were not present in Bacillus spp. isolates from SMP samples. The presence of thermophilic strains of $G$. stearothermophilus, $B$. licheniformis and B. subtilis has been confirmed in both raw milk and milk powders in numerous instances (Phillips \& Griffiths, 1990, Crielly et al. 1994, Murphy et al. 1999).

\section{Pre-identification of Bacillus species isolated from UHT milk:}

The results in Table (5) of Bacillus spp. isolates from defected UHT milk show that $29.41 \%$ of total isolates were able to grow at $7^{\circ} \mathrm{C}$. While, the isolates were not exhibited any growth at $50^{\circ} \mathrm{C}$. On the other hand, results showed that the ability of $94.12 \%$ of isolates to hydrolyze the casein. Bacillus species can cause spoilage in sterilized milk due to their production of proteolytic and lipolytic enzymes or recontamination during the filling of sterilized milk (Chen et al., 2004).

While, results revealed to $43.75 \%$ of isolates were able to hydrolyze the casein and ferment the lactose. Also, $41.18 \%$ of total isolates were able to ferment the lactose. Spoilage of UHT and sterilized milk only occurs occasionally and can mostly attribute to recontamination with proteolytic Bacillus species during the filling step (Schroder, 1984, Foschino et al., 1990). 
Table 3. Pre-identification of Bacillus species isolated from raw milk.

\begin{tabular}{|c|c|c|c|c|c|c|c|c|}
\hline \multirow[b]{2}{*}{ Samples } & \multirow[b]{2}{*}{ Isolates } & \multicolumn{6}{|c|}{ Pre-identification test } & \multirow{2}{*}{$\begin{array}{c}\text { Pre- } \\
\text { identification }\end{array}$} \\
\hline & & $\begin{array}{c}\text { Gram } \\
\text { stain }\end{array}$ & Catalase & $\begin{array}{c}\text { Growth } \\
\text { at } 7^{\circ} \mathrm{C}\end{array}$ & $\begin{array}{l}\text { Growth } \\
\text { at } 50^{\circ} \mathrm{C}\end{array}$ & $\begin{array}{c}\text { Casein } \\
\text { hydrolysis }\end{array}$ & $\begin{array}{c}\text { Lactose } \\
\text { fermentation }\end{array}$ & \\
\hline \multirow{5}{*}{1} & RM1 & + & + & - & - & + & - & Bacillus spp.GE \\
\hline & RM3 & + & + & + & - & + & + & Bacillus spp.GA \\
\hline & RM4 & + & + & - & - & + & - & Bacillus spp.GE \\
\hline & RM5 & + & + & + & - & + & - & Bacillus spp.GB \\
\hline & RM2 & + & + & + & - & + & + & Bacillus spp.GA \\
\hline \multirow{3}{*}{2} & RM3 & + & + & - & - & + & + & Bacillus spp.GD \\
\hline & RM4 & + & + & + & - & + & + & Bacillus spp.GA \\
\hline & RM5 & + & + & - & + & + & + & Bacillus spp.GG \\
\hline \multirow{9}{*}{3} & RM6 & + & + & + & - & + & + & Bacillus spp.GA \\
\hline & RM1 & + & + & - & + & + & + & Bacillus spp.GG \\
\hline & RM3 & + & + & - & - & + & - & Bacillus spp.GE \\
\hline & RM5 & + & + & - & - & + & - & Bacillus spp.GE \\
\hline & RM6 & + & + & - & - & + & - & Bacillus spp.GE \\
\hline & RM7 & + & + & - & + & + & - & Bacillus spp.GH \\
\hline & RM8 & + & + & - & + & + & - & Bacillus spp.GH \\
\hline & RM9 & + & + & - & + & + & - & Bacillus spp.GH \\
\hline & RM10 & + & + & + & - & + & - & Bacillus spp.GB \\
\hline \multirow[t]{2}{*}{4} & RM1 & + & + & - & + & + & - & Bacillus spp.GH \\
\hline & RM1 & + & + & - & + & + & - & Bacillus spp.GH \\
\hline \multirow[t]{3}{*}{5} & RM4 & + & + & - & + & + & - & Bacillus spp.GH \\
\hline & RM1 & + & + & - & - & + & - & Bacillus spp. GE \\
\hline & RM2 & + & + & - & - & + & - & Bacillus spp. GE \\
\hline \multirow[t]{3}{*}{6} & RM3 & + & + & - & - & + & - & Bacillus spp. GE \\
\hline & RM4 & + & + & + & - & + & - & Bacillus spp.GB \\
\hline & RM5 & + & + & + & - & + & + & Bacillus spp.GA \\
\hline 7 & RM3 & + & + & - & - & + & + & Bacillus spp.GD \\
\hline 8 & RM2 & + & + & - & + & + & - & Bacillus spp.GH \\
\hline \multirow[t]{2}{*}{9} & RM3 & + & + & - & + & + & + & Bacillus spp.GG \\
\hline & RM2 & + & + & + & - & + & + & Bacillus spp.GA \\
\hline \multirow[t]{2}{*}{10} & RM3 & + & + & - & + & + & - & Bacillus spp.GH \\
\hline & RM6 & + & + & - & + & + & - & Bacillus spp.GH \\
\hline 11 & RM3 & + & + & + & - & + & + & Bacillus spp.GA \\
\hline \multirow[t]{2}{*}{11} & RM5 & & & & & & & Bacillus spp. GH \\
\hline & RM1 & & & & & & - & Bacillus spp.GB \\
\hline \multirow[t]{2}{*}{12} & RM2 & + & - & + & + & - & + & Bacillus spp.GG \\
\hline & RM3 & + & + & - & + & + & + & Bacillus spp.GG \\
\hline 13 & RM2 & + & + & + & - & + & + & Bacillus spp.GA \\
\hline \multirow[t]{4}{*}{14} & RM1 & + & + & - & + & + & + & Bacillus spp.GG \\
\hline & RM4 & + & + & + & - & + & - & Bacillus spp.GB \\
\hline & RM3 & + & + & - & + & + & - & Bacillus spp.GH \\
\hline & RM4 & + & + & + & - & + & + & Bacillus spp.GA \\
\hline \multirow[t]{3}{*}{15} & RM5 & + & + & - & + & + & - & Bacillus spp.GH \\
\hline & RM6 & + & + & - & + & + & - & Bacillus spp.GH \\
\hline & RM7 & + & + & - & + & + & - & Bacillus spp.GH \\
\hline
\end{tabular}


Cont. Table 3.

\begin{tabular}{|c|c|c|c|c|c|c|c|c|}
\hline \multirow[b]{2}{*}{ Samples } & \multirow[b]{2}{*}{ Isolates } & \multicolumn{6}{|c|}{ Pre-identification test } & \multirow[t]{2}{*}{ Pre-identification } \\
\hline & & $\begin{array}{l}\text { Gram } \\
\text { stain }\end{array}$ & Catalase & $\begin{array}{c}\text { Growth } \\
\text { at } 7^{\circ} \mathrm{C}\end{array}$ & $\begin{array}{l}\text { Growth } \\
\text { at } 50^{\circ} \mathrm{C}\end{array}$ & $\begin{array}{c}\text { Casein } \\
\text { hydrolysis }\end{array}$ & $\begin{array}{c}\text { Lactose } \\
\text { fermentation }\end{array}$ & \\
\hline \multirow{5}{*}{16} & RM1 & + & + & - & + & + & - & Bacillus spp.GH \\
\hline & RM2 & + & + & - & + & + & - & Bacillus spp.GH \\
\hline & RM3 & + & + & - & + & + & - & Bacillus spp.GH \\
\hline & RM4 & + & + & - & + & + & + & Bacillus spp.GG \\
\hline & RM5 & + & + & - & + & + & + & Bacillus spp.GG \\
\hline \multirow{5}{*}{17} & RM1 & + & + & - & - & + & + & Bacillus spp.GD \\
\hline & RM2 & + & + & - & + & + & - & Bacillus spp.GH \\
\hline & RM3 & + & + & - & - & + & + & Bacillus spp.GD \\
\hline & RM4 & + & + & - & - & + & - & Bacillus spp.GE \\
\hline & RM5 & + & + & - & + & + & - & Bacillus spp.GH \\
\hline \multirow{5}{*}{18} & RM1 & + & + & - & + & + & - & Bacillus spp.GH \\
\hline & RM2 & + & + & - & + & + & + & Bacillus spp.GG \\
\hline & RM3 & + & + & - & + & + & + & Bacillus spp.GG \\
\hline & RM4 & + & + & - & + & + & - & Bacillus spp.GH \\
\hline & RM7 & + & + & - & + & + & - & Bacillus spp.GH \\
\hline \multirow{3}{*}{19} & RM1 & + & + & - & + & + & + & Bacillus spp.GG \\
\hline & RM2 & + & + & - & - & + & - & Bacillus spp. GE \\
\hline & RM3 & + & + & - & - & + & - & Bacillus spp. GE \\
\hline \multirow{4}{*}{20} & RM1 & + & + & - & - & + & + & Bacillus spp.GD \\
\hline & RM2 & + & + & - & - & + & - & Bacillus spp.GE \\
\hline & RM4 & + & + & + & - & + & - & Bacillus spp.GB \\
\hline & RM5 & + & + & - & + & + & - & Bacillus spp.GH \\
\hline \multirow[t]{2}{*}{21} & RM4 & + & + & - & + & + & - & Bacillus spp.GH \\
\hline & RM1 & + & + & + & - & + & - & Bacillus spp.GB \\
\hline \multirow[t]{2}{*}{22} & RM2 & + & + & - & - & + & - & Bacillus spp.GE \\
\hline & RM4 & + & + & + & - & + & - & Bacillus spp.GB \\
\hline \multirow[t]{2}{*}{23} & RM1 & + & + & - & + & + & + & Bacillus spp.GG \\
\hline & RM4 & + & + & - & + & + & - & Bacillus spp.GH \\
\hline \multirow[t]{3}{*}{24} & RM5 & + & + & - & + & + & - & Bacillus spp.GH \\
\hline & RM6 & + & + & - & + & + & - & Bacillus spp.GH \\
\hline & RM1 & + & + & - & - & + & - & Bacillus spp.GE \\
\hline \multirow{4}{*}{25} & RM2 & + & + & - & + & + & - & Bacillus spp.GH \\
\hline & RM3 & + & + & + & - & + & - & Bacillus spp.GB \\
\hline & RM4 & + & + & - & + & + & - & Bacillus spp.GH \\
\hline & RM1 & + & + & - & + & + & - & Bacillus spp.GH \\
\hline \multirow[t]{3}{*}{26} & RM3 & + & + & - & - & + & + & Bacillus spp.GD \\
\hline & RM4 & + & + & + & - & + & - & Bacillus spp.GB \\
\hline & RM2 & + & + & - & + & + & - & Bacillus spp.GH \\
\hline \multirow[t]{2}{*}{27} & RM3 & + & + & - & + & + & - & Bacillus spp.GH \\
\hline & RM2 & + & + & - & + & + & + & Bacillus spp.GG \\
\hline \multirow[t]{2}{*}{28} & RM3 & + & + & - & + & + & - & Bacillus spp.GH \\
\hline & RM2 & + & + & - & + & + & - & Bacillus spp.GH \\
\hline \multirow[t]{3}{*}{29} & RM4 & + & + & - & + & + & - & Bacillus spp.GH \\
\hline & RM5 & + & + & - & + & + & + & Bacillus spp.GG \\
\hline & RM2 & + & + & - & + & + & + & Bacillus spp.GG \\
\hline 30 & RM4 & + & + & - & + & + & + & Bacillus spp.GG \\
\hline
\end{tabular}


Cont. Table 3.

\begin{tabular}{|c|c|c|c|c|c|c|c|c|}
\hline \multirow[b]{2}{*}{ Samples } & \multirow[b]{2}{*}{ Isolates } & \multicolumn{6}{|c|}{ Pre-identification test } & \multirow[t]{2}{*}{ Pre-identification } \\
\hline & & $\begin{array}{c}\text { Gram } \\
\text { stain }\end{array}$ & Catalase & $\begin{array}{l}\text { Growth } \\
\text { at } 7^{\circ} \mathrm{C}\end{array}$ & $\begin{array}{l}\text { Growth } \\
\text { at } 50^{\circ} \mathrm{C}\end{array}$ & $\begin{array}{c}\text { Casein } \\
\text { hydrolysis }\end{array}$ & $\begin{array}{c}\text { Lactose } \\
\text { fermentation }\end{array}$ & \\
\hline \multirow{9}{*}{31} & RM1 & + & + & - & - & + & - & Bacillus spp. GE \\
\hline & RM2 & + & + & - & - & + & - & Bacillus spp. GE \\
\hline & RM3 & + & + & - & - & + & + & Bacillus spp.GD \\
\hline & RM4 & + & + & - & + & + & - & Bacillus spp.GH \\
\hline & RM5 & + & + & - & + & + & + & Bacillus spp.GG \\
\hline & RM6 & + & + & - & + & + & - & Bacillus spp.GH \\
\hline & RM7 & + & + & - & + & + & + & Bacillus spp.GG \\
\hline & RM8 & + & + & - & - & + & - & Bacillus spp.GE \\
\hline & RM1 & + & + & - & - & + & + & Bacillus spp.GD \\
\hline \multirow{3}{*}{32} & RM2 & + & + & - & + & + & - & Bacillus spp.GH \\
\hline & RM3 & + & + & - & + & + & + & Bacillus spp.GG \\
\hline & RM4 & + & + & - & - & + & - & Bacillus spp.GE \\
\hline
\end{tabular}

A: Bacillus isolates grow at $7,32^{\circ} \mathrm{C}$, hydrolyze casein \& lactose ferment. B: Bacillus isolates grow at $7,32^{\circ} \mathrm{C} \&$ hydrolyze casein. C: Bacillus isolates grow at $7,32^{\circ} \mathrm{C} \&$ lactose ferment.

D: Bacillus isolates grow at $32^{\circ} \mathrm{C}$, hydrolyze casein \& lactose ferment. $\quad$ E: Bacillus isolates grow at $32^{\circ} \mathrm{C} \&$ hydrolyze casein.

F: Bacillus isolates grow at $32^{\circ} \mathrm{C} \&$ lactose ferment.

$\mathrm{G}$ : Bacillus isolates grow at $32,50^{\circ} \mathrm{C}$, hydrolyze casein \& lactose ferment.

$\mathrm{H}$ : Bacillus isolates grow at $32,50^{\circ} \mathrm{C} \&$ hydrolyze casein.

I: Bacillus isolates grow at $32,50^{\circ} \mathrm{C} \&$ lactose ferment

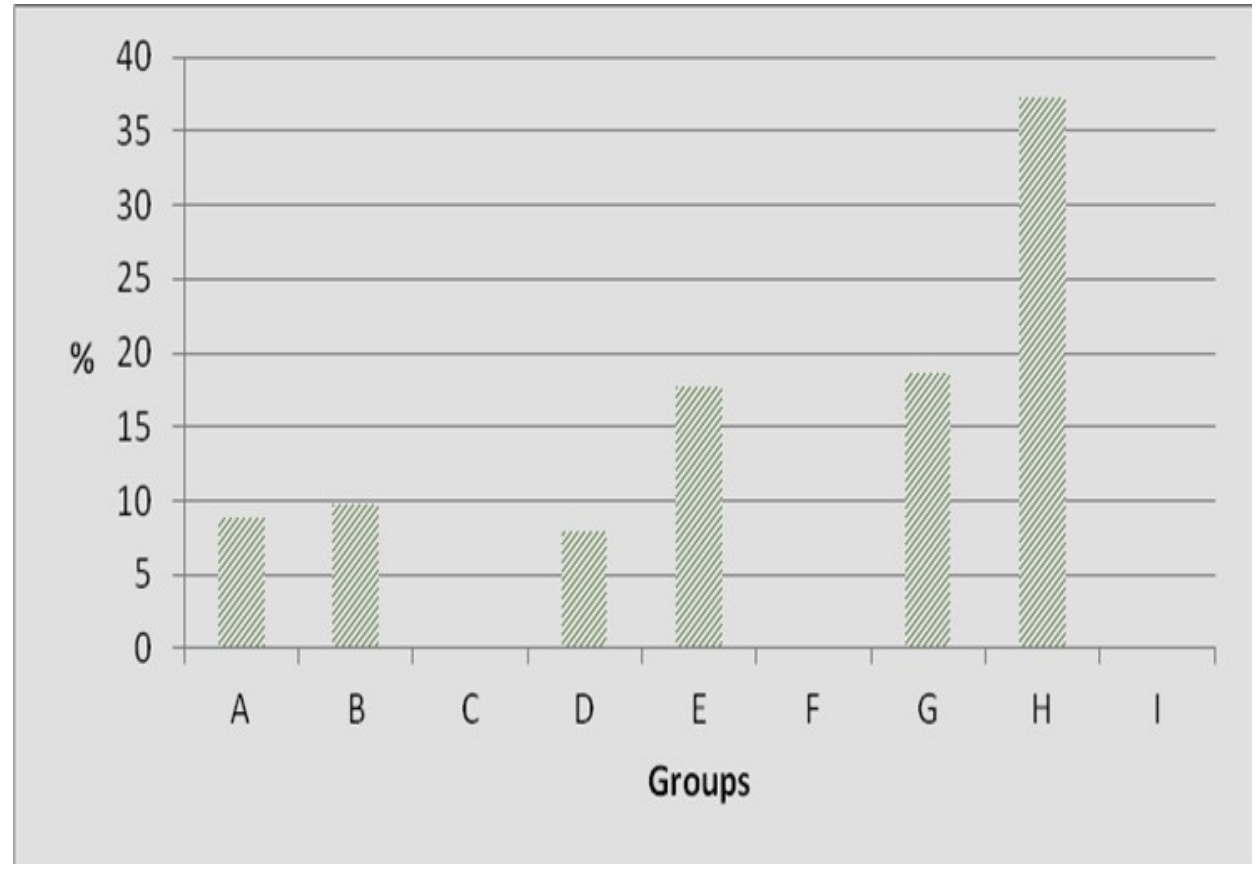

Figure 1. Classification of Bacillus species isolated from raw milk.

A: Bacillus isolates grow at $7,32^{\circ} \mathrm{C}$, hydrolyze casein \& lactose ferment. B: Bacillus isolates grow at $7,32^{\circ} \mathrm{C} \&$ hydrolyze casein.

C: Bacillus isolates grow at $7,32^{\circ} \mathrm{C} \&$ lactose ferment.

D: Bacillus isolates grow at $32^{\circ} \mathrm{C}$, hydrolyze casein \& lactose ferment. $\quad$ E: Bacillus isolates grow at $32^{\circ} \mathrm{C} \&$ hydrolyze casein.

F: Bacillus isolates grow at $32^{\circ} \mathrm{C} \&$ lactose ferment.

G: Bacillus isolates grow at $32,50^{\circ} \mathrm{C}$, hydrolyze casein \& lactose ferment.

$\mathrm{H}$ : Bacillus isolates grow at $32,50^{\circ} \mathrm{C} \&$ hydrolyze casein. $\quad$ I: Bacillus isolates grow at $32,50^{\circ} \mathrm{C} \&$ lactose ferment. 
Table 4. Pre-identification of Bacillus species isolated from skim milk powder

\begin{tabular}{|c|c|c|c|c|c|c|c|c|}
\hline \multirow[b]{2}{*}{ Samples } & \multirow[b]{2}{*}{ Isolates } & \multicolumn{6}{|c|}{ Pre-identification test } & \multirow{2}{*}{$\begin{array}{l}\text { Pre- } \\
\text { identification }\end{array}$} \\
\hline & & $\begin{array}{c}\text { Grams' } \\
\text { stain }\end{array}$ & Catalase & $\begin{array}{c}\text { Growth } \\
\text { at } 7^{\circ} \mathrm{C}\end{array}$ & $\begin{array}{l}\text { Growth } \\
\text { at } 50^{\circ} \mathrm{C}\end{array}$ & $\begin{array}{c}\text { Casein } \\
\text { hydrolysis }\end{array}$ & $\begin{array}{c}\text { Lactose } \\
\text { ermentation }\end{array}$ & \\
\hline \multirow{4}{*}{1} & SMP1 & + & + & - & + & + & + & Bacillus spp.GG \\
\hline & SMP2 & + & + & - & - & + & - & Bacillus spp.GE \\
\hline & SMP3 & + & + & - & + & + & + & Bacillus spp.GG \\
\hline & SMP2 & + & + & - & - & + & - & Bacillus spp.GE \\
\hline \multirow{3}{*}{2} & SMP3 & + & + & - & - & + & + & Bacillus spp.GD \\
\hline & SMP4 & + & + & - & + & + & + & Bacillus spp.GG \\
\hline & SMP5 & + & + & - & + & + & + & Bacillus spp.GG \\
\hline \multirow{4}{*}{3} & SMP1 & + & + & - & + & - & + & Bacillus spp.GI \\
\hline & SMP3 & + & + & - & + & + & + & Bacillus spp.GG \\
\hline & SMP4 & + & + & - & + & + & + & Bacillus spp.GG \\
\hline & SMP1 & + & + & - & + & - & + & Bacillus spp.GI \\
\hline \multirow{2}{*}{4} & SMP2 & + & + & - & - & + & + & Bacillus spp.GD \\
\hline & SMP3 & + & + & - & - & + & + & Bacillus spp.GD \\
\hline \multirow{3}{*}{5} & SMP2 & + & + & - & - & + & - & Bacillus spp.GE \\
\hline & SMP3 & + & + & - & + & + & - & Bacillus spp.GH \\
\hline & SMP1 & + & + & - & + & + & + & Bacillus spp.GG \\
\hline \multirow{3}{*}{6} & SMP2 & + & + & - & - & + & + & Bacillus spp.GD \\
\hline & SMP3 & + & + & - & - & + & + & Bacillus spp.GD \\
\hline & SMP5 & + & + & - & + & - & + & Bacillus spp.GI \\
\hline \multirow{4}{*}{7} & SMP1 & + & + & - & + & + & - & Bacillus spp.GH \\
\hline & SMP2 & + & + & - & - & + & + & Bacillus spp.GD \\
\hline & SMP3 & + & + & - & + & + & + & Bacillus spp.GG \\
\hline & SMP2 & + & + & - & + & + & + & Bacillus spp.GG \\
\hline \multirow{2}{*}{8} & SMP3 & + & + & - & + & + & + & Bacillus spp.GG \\
\hline & SMP4 & + & + & - & + & + & - & Bacillus spp.GH \\
\hline
\end{tabular}

A: Bacillus isolates grow at $7,32^{\circ} \mathrm{C}$, hydrolyze casein \& lactose ferment.

B: Bacillus isolates grow at $7,32^{\circ} \mathrm{C} \&$ hydrolyze casein. $\quad$ C: Bacillus isolates grow at $7,32^{\circ} \mathrm{C} \&$ lactose ferment.

D: Bacillus isolates grow at $32^{\circ} \mathrm{C}$, hydrolyze casein \& lactose ferment.

E: Bacillus isolates grow at $32^{\circ} \mathrm{C} \&$ hydrolyze casein. $\quad F$ : Bacillus isolates grow at $32^{\circ} \mathrm{C} \&$ lactose ferment.

$\mathrm{G}$ : Bacillus isolates grow at $32,50^{\circ} \mathrm{C}$, hydrolyze casein \& lactose ferment.

$\mathrm{H}$ : Bacillus isolates grow at $32,50^{\circ} \mathrm{C} \&$ hydrolyze casein. $\quad$ I: Bacillus isolates grow at $32,50^{\circ} \mathrm{C} \&$ lactose ferment.

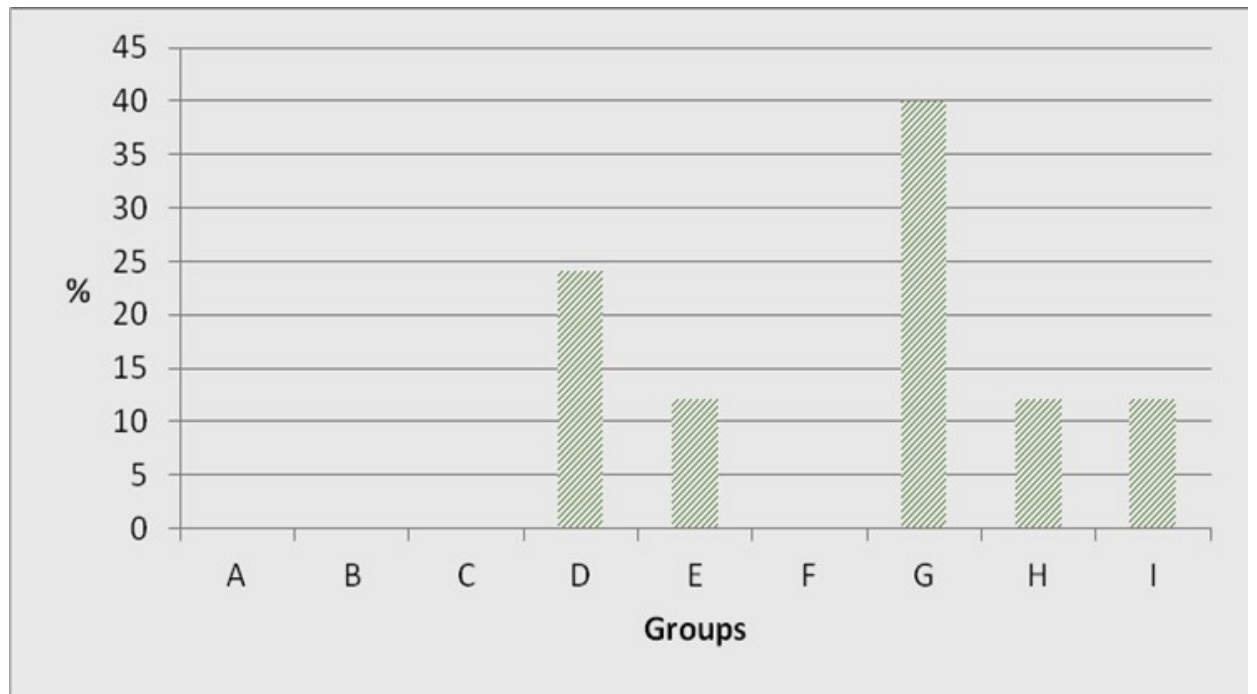

Figure 2. Classification of Bacillus species isolated from skim milk powder 
Table 5. Pre-identification of Bacillus species isolated from UHT milk

\begin{tabular}{|c|c|c|c|c|c|c|c|c|}
\hline \multirow[b]{2}{*}{ Samples } & \multirow[b]{2}{*}{ Isolates } & \multicolumn{6}{|c|}{ Pre-identification test } & \multirow[b]{2}{*}{$\begin{array}{c}\text { Pre- } \\
\text { identification }\end{array}$} \\
\hline & & $\begin{array}{c}\text { Grams' } \\
\text { stain }\end{array}$ & Catalase & $\begin{array}{c}\text { Growth } \\
\text { at } 7^{\circ} \mathrm{C}\end{array}$ & $\begin{array}{l}\text { Growth } \\
\text { at } 50^{\circ} \mathrm{C}\end{array}$ & $\begin{array}{l}\text { Hydrolyze } \\
\text { the casein }\end{array}$ & $\begin{array}{c}\text { Lactose } \\
\text { fermentation }\end{array}$ & \\
\hline \multirow[t]{2}{*}{2} & UHT1 & + & + & + & - & + & - & Bacillus spp.GB \\
\hline & UHT2 & + & + & + & - & + & - & Bacillus spp.GB \\
\hline 4 & UHT1 & + & + & + & - & + & + & Bacillus spp.GA \\
\hline \multirow[t]{2}{*}{5} & UHT1 & + & + & - & - & + & - & Bacillus spp.GE \\
\hline & UHT2 & + & + & - & - & + & - & Bacillus spp.GE \\
\hline 7 & UHT1 & + & + & - & - & + & - & Bacillus spp.GE \\
\hline 8 & UHT1 & + & + & - & - & + & + & Bacillus spp.GD \\
\hline \multirow[t]{2}{*}{9} & UHT1 & + & + & - & - & + & - & Bacillus spp.GE \\
\hline & UHT2 & + & + & - & - & + & - & Bacillus spp.GE \\
\hline \multirow[t]{2}{*}{11} & UHT1 & + & + & + & - & + & + & Bacillus spp.GA \\
\hline & UHT2 & + & + & - & - & - & + & Bacillus spp.GF \\
\hline 12 & UHT1 & + & + & - & - & + & - & Bacillus spp.GE \\
\hline 14 & UHT2 & + & + & - & - & + & + & Bacillus spp.GD \\
\hline \multirow[t]{2}{*}{15} & UHT1 & + & + & - & - & + & + & Bacillus spp.GD \\
\hline & UHT2 & + & + & - & - & + & - & Bacillus spp.GE \\
\hline 16 & UHT1 & + & + & - & - & + & + & Bacillus spp.GD \\
\hline 17 & UHT1 & + & + & + & - & + & - & Bacillus spp.GB \\
\hline
\end{tabular}

A: Bacillus isolates grow at $7,32^{\circ} \mathrm{C}$, hydrolyze casein \& lactose ferment. B: Bacillus isolates grow at $7,32^{\circ} \mathrm{C} \&$ hydrolyze casein C: Bacillus isolates grow at $7,32^{\circ} \mathrm{C} \&$ lactose ferment.

D: Bacillus isolates grow at $32^{\circ} \mathrm{C}$, hydrolyze casein \& lactose ferment. $\quad$ E: Bacillus isolates grow at $32^{\circ} \mathrm{C} \&$ hydrolyze casein.

F: Bacillus isolates grow at $32^{\circ} \mathrm{C} \&$ lactose ferment.

$\mathrm{G}$ : Bacillus isolates grow at $32,50^{\circ} \mathrm{C}$, hydrolyze casein \& lactose ferment.

$\mathrm{H}$ : Bacillus isolates grow at $32,50^{\circ} \mathrm{C} \&$ hydrolyze casein. $\quad$ I: Bacillus isolates grow at $32,50^{\circ} \mathrm{C} \&$ lactose ferment.

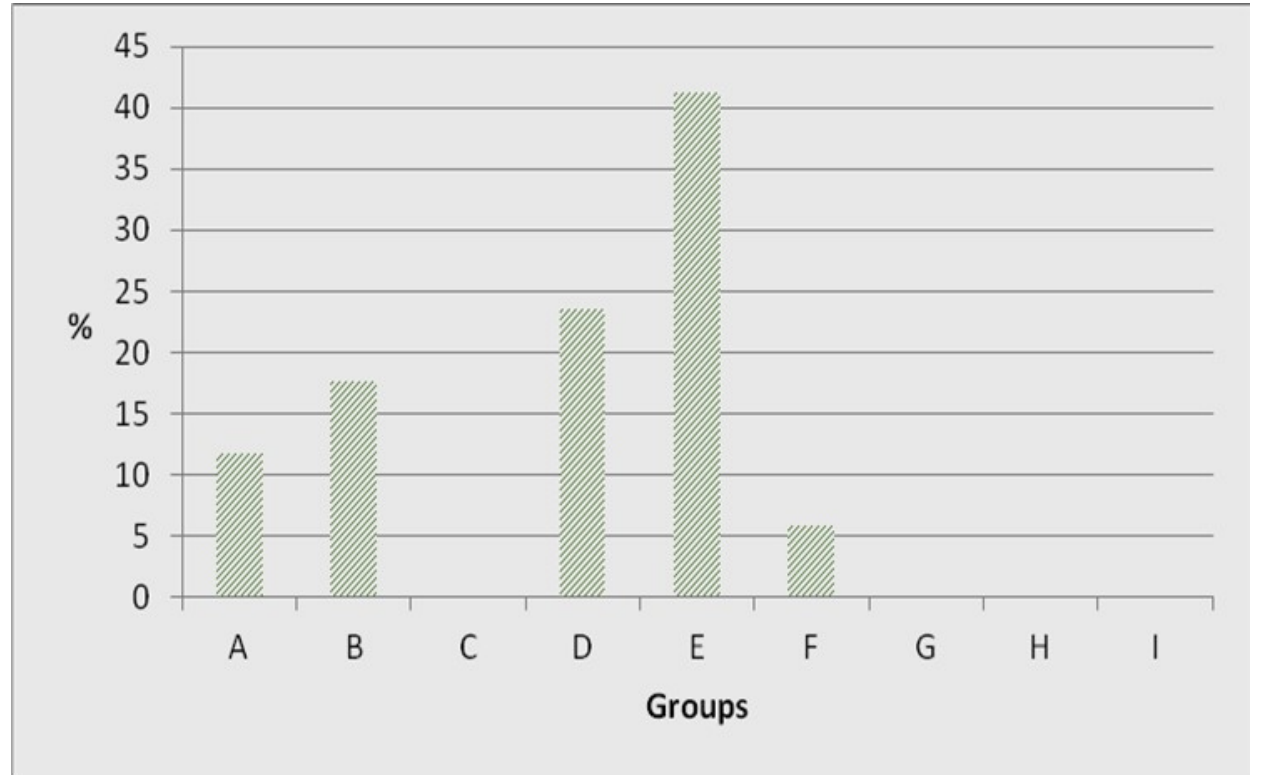

Figure 3.Classification of Bacillus species isolated from UHT milk

A: Bacillus isolates grow at $7,32^{\circ} \mathrm{C}$, hydrolyze casein \& lactose ferment. B: Bacillus isolates grow at $7,32^{\circ} \mathrm{C} \&$ hydrolyze casein.

C: Bacillus isolates grow at $7,32^{\circ} \mathrm{C} \&$ lactose ferment.

D: Bacillus isolates grow at $32^{\circ} \mathrm{C}$, hydrolyze casein \& lactose ferment. $\quad$ E: Bacillus isolates grow at $32^{\circ} \mathrm{C} \&$ hydrolyze casein.

F: Bacillus isolates grow at $32^{\circ} \mathrm{C} \&$ lactose ferment.

$\mathrm{G}$ : Bacillus isolates grow at $32,50^{\circ} \mathrm{C}$, hydrolyze casein \& lactose ferment.

$\mathrm{H}$ : Bacillus isolates grow at $32,50^{\circ} \mathrm{C} \&$ hydrolyze casein. $\quad$ I: Bacillus isolates grow at $32,50^{\circ} \mathrm{C} \&$ lactose ferment. 
All psychrotrophic Bacillus ssp. Isolates were able to hydrolyze the casein. At the same time $40 \%$ of these isolate were able to ferment the lactose. Bahout (2000) mentioned that the presence of $B$. cereus in UHT milk. On the other hand, $91.67 \%$ of mesophilic Bacillus ssp. isolates were able to hydrolyze the casein and $36.36 \%$ of isolates able to hydrolyze the casein were able to ferment the lactose.

As shown in Fig. (3) Bacillus spp. isolates from UHT milk samples were classified to 5 groups according to data given in Table (2). The group E (41.18\%) was the predominant group, group D $(23.53 \%)$, group B (17.65\%), group A (11.76\%) and group F $(5.88 \%)$ were also present. While, noticed that the groups C, G, H and I were not present in Bacillus spp. isolates from UHT milk samples. Klijn et al. (1997), Montanari et al. (2004) demonstrated that B. sporothermodurans was the predominant sporigenous micro-organisms in UHT milk. Cosentino et al. (1997) reported the presence of aerobic spore formers, including $B$. sphaericus, $B$. licheniformis and B. brevis, in Sardinian UHT milk samples.

Burton (1988) reported that Bacillus stearothermophilus and Bacillus licheniformis may be of the most thermophilic spore formers commonly found in UHT milk and dairy products. While, as stated by Datta \& Deeth (2007) Bacillus stearothermophilus and Bacillus flavothermus spores can be so great in milk powder that UHT processing is ineffective as a commercial sterilization method.

\section{CONCLUSION}

Raw milk, skimmed milk powder and some of UHT milk samples were contaminated with aerobic sporeforming bacteria. Isolates from raw milk were psychrotrophic, mesophilic and thermophilic Bacillus species. Isolates from Skimmed milk powder were mesophilic and thermophilic Bacillus species. While, isolates from UHT milk were psychrotrophic and mesophilic Bacillus species. There were differences among isolates in ability to hydrolyze the casein and ferment lactose. There for future works is concluded to identify the isolates by molecular methods and prevent or reduce the spore forming bacterial counts in raw milk to enhance the quality of UHT milk in Egypt.

\section{REFERENCES}

Bahout A.A. 2000. Prevalence of Bacillus species in UHT milk. Assoc. Vet. Med. J., 42: 47-53.

Burgess S.A., J.D. Brooks, J. Rakonjac, K.M.Walker and S.H. Flint .2009.The formation of spores in biofilms of Anoxybacillus flavithermus. Journal of Applied Microbiology, 107:1012-1018.
Burgess S.A., D. Lindsay and S.H. Flint .2010.Thermophilic bacilli and their importance in dairy processing. International Journal of Food Microbiology, 144: 215225.

Burton H.1988. Ultra-High-Temperature Processing of Milk and Milk Products, New York, Elsevier Science Publishing Co., Inc.

Chen L., T. Coolbear and R.M. Daniel .2004. Characteristics of proteinases and lipases produced by seven Bacillus sp. Isolated from milk powder production lines. International Dairy Journal, 14: 495-504.

Cook G. and R. Sandeman .2000.Sources and characterization of sporeforming bacteria in raw milk. Australian Journal of Dairy Technology, 55: 119-126.

Coorevits A., V. De Jonghe, J. Vandroemme, R. Reekmans, J. Heyrman, W. Messens, P. De Vos, and M. Heyndrickx .2008.Comparative analysis of the diversity of aerobic spore-forming bacteria in raw milk from organic and conventional dairy farms. Systematic and Applied Microbiology, 31: 126-140.

Cosentino S., A. F. Mulargia, B.Pisano, P.Tuveri and F. Palmas .1997. Incidence and biochemical characteristics of Bacillus flora in Sardinian dairy products. International Journal of Food Microbiology. 38:235-238.

Crielly E., N. Logan and A. Anderton .1994. Studies on the Bacillus flora of milk and milk products. Journal of Applied Microbiology, 77: 256-263.

Datta N. and H.C. Deeth .2007. Advances in Thermal and Non-Thermal Food Preservation, Ames, Iowa, Blackwell Pulishing, pp. 63-90.

Deeth H.C.2010. Improving UHT techniques. In Mansel W. Griffiths (Ed.), Improving the safety and quality of milk (pp. 302-329) Cambridge, U.K.: Woodhead.

Difco's manual of dehydrated culture media and reagents for microbiology .(1984) $.10^{\text {th }}$ ed. Pub. Difco's laboratories, Detroit MchiGan. U.S.A.

Fernanda D. N., U.S. Rosangela, M. Claudio and F. Hans .2010. Occurrence of Bacillus sporothermodurans in UHT Milk Commercialized in the state of Rio Grande Do Sul, Brazil. Global Veterinaria, 4:156-159.

Foschino R., A.Galli and G. Ottogalli .1990. Research on microflora of UHT milk. Annals of Microbiology, 40:4759.

Hammer P., F. Lembke, Suhren, G. and W. Heeschen .1995. Characterization of a heat resistant mesophilic Bacillus species affecting quality of UHT-milk-a preliminary report. Kiel Milchwirtsch Forschungsber, 47: 303-311.

Heyndrickx M. and P. Scheldeman .2002. Bacilli associated with spoilage in dairy products and other food. In Applications and systematics of Bacillus and relatives (pp. 64-82). MA: Blackwell Science Ltd.

Holt J.G., N.R. Krieg, P.H.A. Sneath, J.T. Staley and S.T. Williams .1994. Bergey's Manual of Determinative Bacteriology. Endospore Forming Gram Positive Rods and Cocci, 9:559. 
Huck J., B. Hammond, S. Murphy, N.Woodcock and K. Boor .2007. Tracking sporeforming bacterial contaminants in fluid milk-processing systems. Journal of Dairy Science, 90:48-72.

Kessler H.G. 2002. Food and Bio Process Engineering Dairy Technology, 5th ed. 130-215.

Klijn N., L. Herman, L. Langeveld, M. Vaerewijck, A. Wagendorp, I. Huemer and A. Weerkamp.1997. Genotypical and phenotypical characterization of Bacillus sporothermodurans strains, surviving UHT sterilization. International Dairy Journal, 7: 421-428.

Lewis M. J. and H. C. Deeth .2009. Heat treatment of milk. In A. Y. Tamime (Ed.), Milk processing and quality management (pp. 168e204). West Sussex: Blackwell Publishing Ltd.

Logan N.A. and P. DeVos .2009. Genus I. Bacillus. In: De Vos P., Garrity G.M., Jones D., Krieg N.R., Ludwig W., Rainley F.A., Schleifer, K. H., Whitman W.B. (eds): Bergey's Manual of Systematic Bacteriology. Springer Science + Business Media, New York: 21-108.

McGuiggan J.T.M., D.R. McCleery, A. Hannan and A. Gilmour .2002. Aerobic spore-forming bacteria in bulk raw milk: Factors influencing the numbers of psychrotrophic, mesophilic and thermophilic Bacillus spores, International Journal of Dairy Technology, 55:100-107.

Megha S. V. and B. Annadurai .2014. Isolation and identification of proteolytic bacteria from raw milk samples. Global Journal of Bio-science and Biotechnology, 3:391-397.

Mikolajcik E. M. and N. T. Simon .1978. Heat resistant psychrotrophic bacteria in raw milk and their growth at 7॰C. Journal of Food Protection, 41: 3-95.

Montanari G., A. Borsari, C. Chiavari, G. Ferri, C. Zambonelli and L. Grazia .2004. Morphological and phenotypical characterization of Bacillus sporothermodurans. Journal of Applied Microbiology, 97: 802-809.

Murphy P.M., D. Lynch and P.M. Kelly.1999. Growth of thermophilic spore forming bacilli in milk during the manufacture of low heat powders. Int. J. Dairy Technology, 52: 45-50.

Phillips J. D. and M. W. Griffiths .1990. Pasteurised dairy products: constraints imposed by environmental contamination.In Food contamination from environmental sources, pp. 387-456 (Eds JO Nriagu\& MS Simmons). USA: John Wiley and Sons.
Priest F.1993. Systematics and Ecology of Bacillus, p 316. In Sonenshein A, Hoch J, Losick R (ed), Bacillus subtilis and Other Gram-Positive Bacteria. ASM Press, Washington, DC.

Scheldeman P., L. Herman, S. Foster and M. Heyndrickx .2006. Bacillus sporothermodurans and other highly heatresistant spore formers in milk. Journal of Applied Microbiology, 101: 542-555.

Scheldeman P., A. Pil, L. Herman, P. De Vos, and M. Heyndrickx .2005. Incidence and diversity of potentially highly heat-resistant spores isolated at dairy farms. Applied and Environmental Microbiology: 71, 14801494.

Schroder M. J. A. 1984. Origin and levels of post pasteurization contamination of milk in the dairy industry and the effects on keeping quality. Journal of Dairy Research, 51:59-67.

Slepecky R.A. and Hemphill, H.E.2006. The genus Bacillusnonmedical. In: Dworkin M., Falkow S., Rosenberg E., Schleifer K. (eds): The Prokaryotes. A Handbook of the Biology of Bacteria. Springer Science + Business Media, New York: 530-555.

Srilakshmi B.1999. Food science. New age International private limited publishers, Delhi. pp \# 521.

Standard Methods for the Examination of Dairy products. (1978). 14 $4^{\text {th }}$ Edition Washington, American public Health Association, Inc. edited by Marth, $\mathrm{H}$.

Stenfors L.P. and P.E. Granum .2001. Psychrotolerant species from The Bacillus cereus group are not necessarily Bacillus weihenstephanensis. FEMS Microbiol. Lett., 197: 223-228.

Webb R., M. Lising, K. Reece and M. Healy .2003. Identification and Strain Differentiation of Bacillus Species using Automated rep-PCR DNA Fingerprinting. Bacterial Bar Codes, Inc., Houston, Texas, USA.

Wong H., M. Chang and J. Fan .1988. Incidence and characterization of Bacillus cereus isolates contaminating dairy products. Applied and environmental microbiology, 54: 699-702.

Zewail.M.Z., M. M. Kandil, M.S. El-Shahaat , M.H. ElHalfway and A.M. El-Mare.2015. Residues and Dissipation of Imidacloprid, Oxamyl, and Emamectin Benzoate in Greenhouse Grown Tomato Fruits and Their Influence on Lycopene Content. Alex.Sci.Exch.J.36(1):16. 


\section{الملخص العربي}

\section{صفات البكتيريا المتجرثمة الهوائية المعزولة من اللبن الخام، اللبن الفرز المجفف واللبن المعقم}

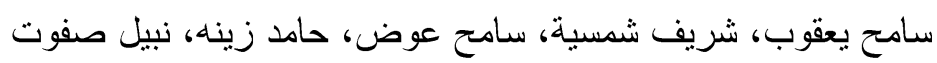

تم تصنيفها اعتمادا على الاختبارات المورفولوجية،

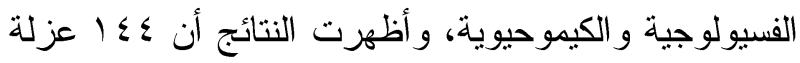

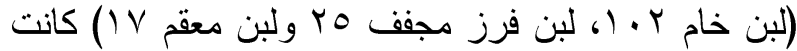
أنو اع بكتيرية تابعة لجنس الباسيلس (Bacillus)، وتم تقييم النشاط التحللى والقدرة على تخمير اللاكتوز لهذه العزلات ،ووجد أن 97,00\% لها القدرة على تحليل الكازين،

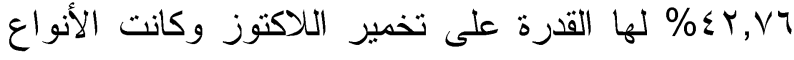
البكتيرية من جنس الباسيلس (Bacillus) المحبة لدرجة الحرارة المرتفعة هى السائدة فى عينات اللبن الخام و اللبن

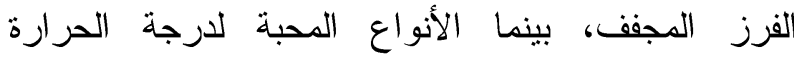
المتوسطة كانت هى السائدة فى عينات اللبن المعقم.
البكتبريا المتجرثمة المقاومة للحرارة و المحبة للحرارة

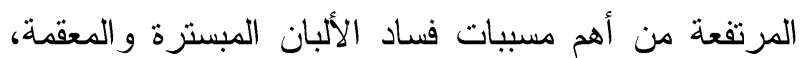
حيث أن وجود هذه البكتيريا بأعداد كبيرة فى اللبن الخام

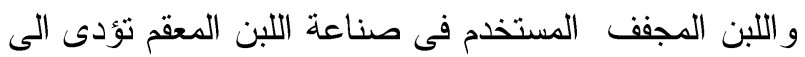
حدوث فساد أو تقليل فترة الصلاحية للمنتج النهائى. لذلك أجريت هذه الدراسة بهدف عزل والتعرف على البكتيريا

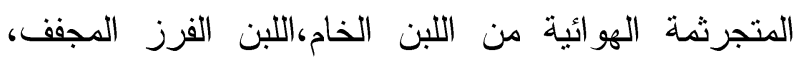

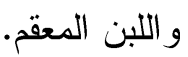

تم تجميع •ـ أ عينة من اللبن الخام (rس)، اللبن الفرز

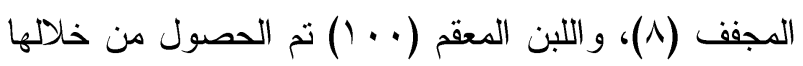

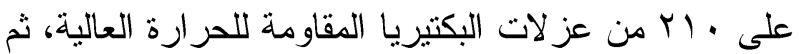

